\title{
Natural factors of technological accidents: the case of Russia
}

\author{
E. G. Petrova \\ Faculty of Geography, Lomonosov Moscow State University, 119991, GSP-1, Moscow, Russia \\ Received: 8 January 2011 - Revised: 24 April 2011 - Accepted: 27 June 2011 - Published: 16 August 2011
}

\begin{abstract}
The data base of technological accidents and disasters that have occurred in Russia has been created. More than 13000 information units have been collected and analyzed. The proportion of accidents triggered by natural events (natural-technological accidents or NTA) in the total number of technological accidents as well as a part of every NTA type in the total number of NTA was estimated. About 10 percent of all accidents registered in the data base were caused by natural events; among some types of accidents this proportion is even higher. Transmission facilities with more than 90 percent of overhead lines are the most vulnerable to the impact of natural hazards. The contribution of different natural hazards was evaluated. Regions with the greatest NTA risk were revealed. The influence of natural events on the technosphere is stronger in the South of the European Russia and in the Russian Far East, which are more exposed to hurricanes, snowstorms, rainfalls, icing and other natural hazards producing NTA. The critical infrastructure needs special protection and modernization in these regions. The problem of the relationship between natural hazards and the technosphere is very complicated and needs further investigation, especially taking the expected climate changes into consideration.
\end{abstract}

\section{Introduction}

The catastrophic consequences of the 9-magnitude earthquake and devastating tsunami that struck the northeast coast of Honshu Island in Japan on 11 March 2011, has become yet another tragic confirmation of the vulnerability of the technosphere and society, even such a highly developed one as the Japanese, to the impacts of natural hazards. The disaster

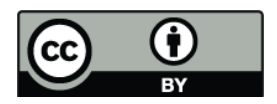

Correspondence to: E. G. Petrova (epgeo@mail.ru) has shown once again that in addition to direct social, economic, and environmental damage, natural catastrophes can cause even more dire consequences because of the technological accidents and disasters triggered by them. The extent of these consequences depends on the population density and concentration of infrastructure and industrial facilities (especially hazardous objects, such as nuclear power plants, chemical plants, refineries, and pipelines) in disaster-affected areas.

The lesson learnt from the Japanese disaster was its synergistic nature: the earthquake's impact increased due to the ensuing tsunami and multiple technological accidents including the severe accident at the Fukushima nuclear plant, fires in Chiba and Sendai refineries, and others. All of these accidents were triggered simultaneously, which made coping with each of them much more difficult and intensified the severity of their consequences. Moreover, the lifelines and roads needed for fighting the accidents were damaged by the natural disaster. Various natural-technological accidents and disasters have become more frequent during the last decades in the world in general and in Russia, in particular, which makes investigation of these accidents and disasters especially important. It is their synergistic character, which distinguishes them from either natural disasters or a single technological disasters. Increasing in number and severity of natural-technological accidents is caused, on the one hand, by the growing frequency and intensity of natural hazards due to climate change, and on the other hand by the much more complicated structure of modern technological systems exposed to natural risk.

A natural-technological accident (disaster) is considered in this paper as any kind of incident in the technosphere triggered by any natural event. It should be mentioned that this study deals with a broader range of technological accidents and disasters induced by natural factors than the so-called Natech risk assessment does. Showalter and Myers (1994), Young et al. (2004), Steinberg and Cruz (2004), Krausmann

Published by Copernicus Publications on behalf of the European Geosciences Union. 


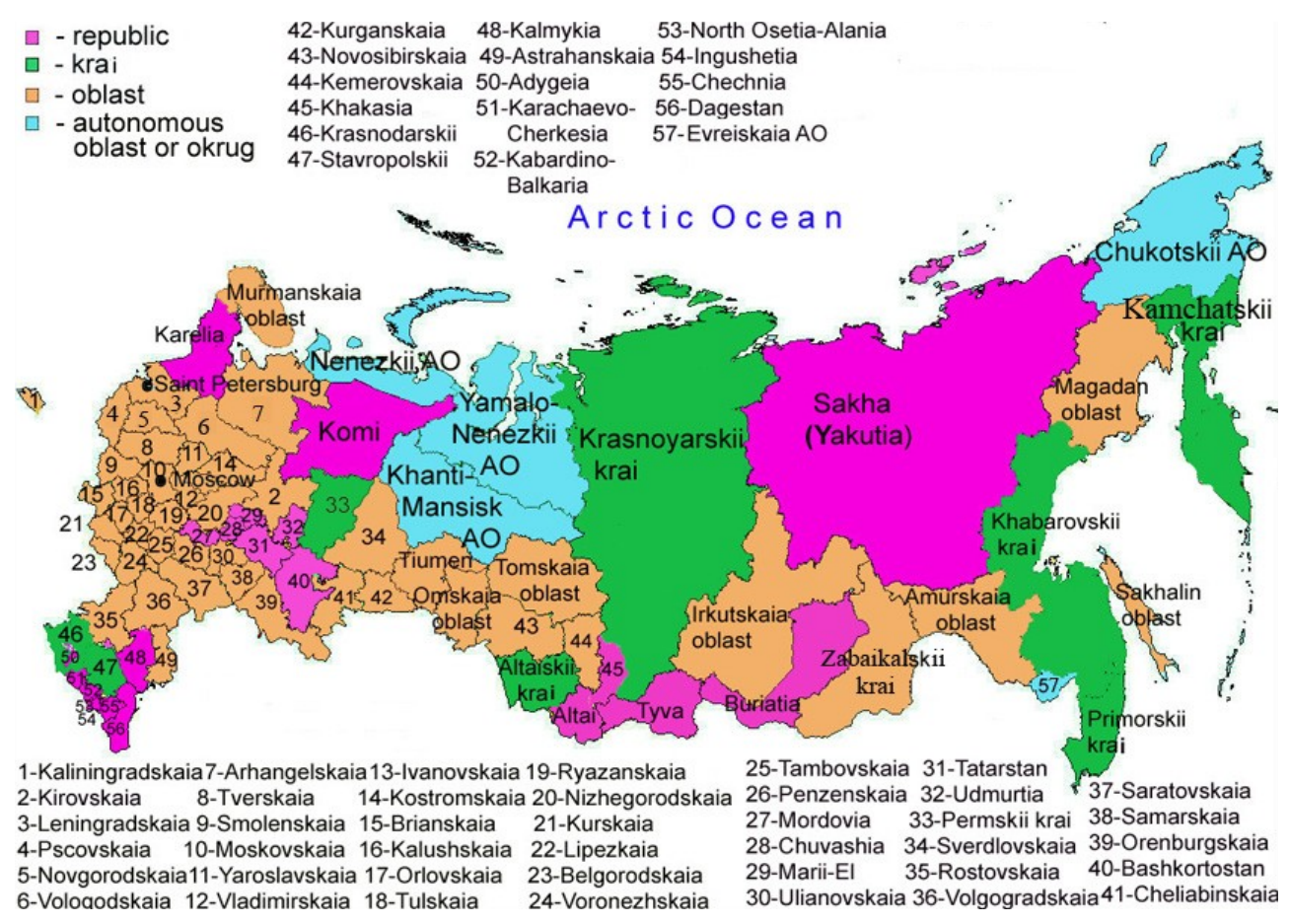

Fig. 1. Administrative division of the Russian Federation.

and Cruz (2008) regard Natechs as natural-disaster-triggered spills and releases from fixed chemical installations, as well as oil and gas spills from pipelines. The present study includes also natural-event impacts on other critical infrastructures, industrial and transport facilities causing any accidents, failures, and crashes.

The EMERCOM of Russia (the Ministry of the Russian Federation for Civil Defense, Emergencies and Elimination of Consequences of Natural Disasters) uses the concept of emergencies for reporting accidents in its official summaries. An emergency is considered as a situation disturbing the current activity of a populated region due to an abrupt technological/natural impact resulting in social, economic, or ecological damage, which requires special management efforts for its elimination. The criteria of an emergency are as follows: it is a situation causing four or more fatalities, injuring 10 or more people, disturbing living conditions of 100 or more people, or having a large damage (more than 100000 Euro). Only accidents producing emergencies are reported by the Ministry. The same criteria are used in this paper.

The main purpose of this study is to find out natural triggers of technological accidents and disasters in Russia, to reveal their proportion among other causes of accidents, to identify the contribution of different natural hazards, and to trace regional differences in their manifestation.

\section{Research regions}

The Russian Federation (RF) is the subject of this research. Analysis was undertaken at the level of its main administrative units (federal regions). These units correspond to states in the USA, federal states in Germany, or provinces in China. Official statistical data in Russia are usually published for these units, which represent the highest administrative level.

The Russian Federation consists now of 83 federal regions (Fig. 1), including 21 republics (such as Karelia Republic, Komi Republic, the Republic of Dagestan, etc.), nine kraies or territories (such as Krasnodar Krai/Territory, Krasnoyarsk Krai/Territory, Stavropol Krai/Territory, etc.), 46 oblasts or regions (such as Moskovskaya Oblast' or the Moscow Region, Leningradskaya Oblast', etc.), one autonomous oblast'/autonomous region (Evreyskaya AO), and four autonomous okrugs/autonomous districts (such as Khanti-Mansisk AO and Chukotskii AO). The two largest Russian cities, Moscow and Saint Petersburg, are separate federal regions too.

\section{Methods}

An electronic data base of technological accidents and disasters in the Russian Federation has been created using daily summaries of the EMERCOM of Russia, mass media news reports, and other open sources of information such as input data. Occurrence time and location, type of accident, number of fatalities and injured people, the value of economic losses, 


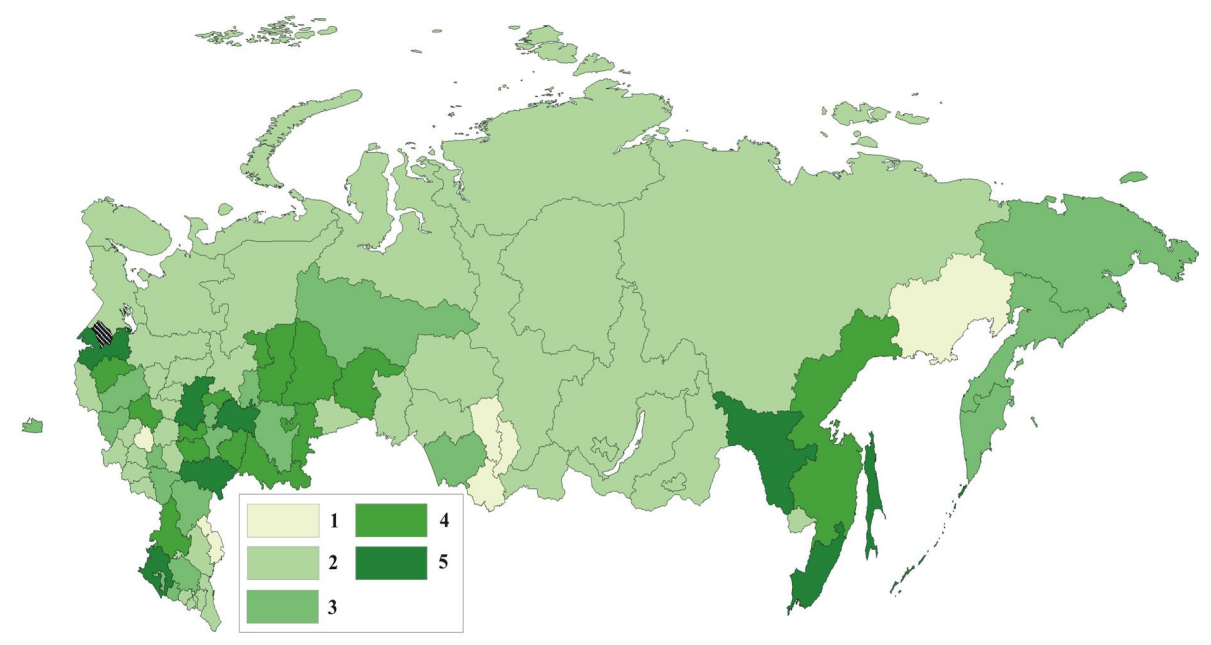

Fig. 2. Frequency of NTA triggered by strong winds (average annual number of events): $1-$ less than $0.1 ; 2-0.1-0.3 ; 3-0.4-0.6 ; 4-$ more than 0.6.

a short description of every accident including a probable cause, extent of damage, and environmental consequences, as well as source of information are listed. More than 13000 information units have been collected in the data base; new information is constantly being added to it. The criteria for an emergency mentioned above are used for an accident to be included in the data base.

Occurrence frequency of every technological accident type (fires and explosions; car and aircraft crashes; railway accidents; power-, heat-, and water-supply breakdowns; pipeline ruptures and other accidents with contaminant releases; shipwrecks; sudden collapses of buildings or constructions, etc.) was statistically assessed for 1991-2010 at the level of the Russian main administrative units using collected data. For this purpose, the average annual number of events for every accident type and each federal region was calculated within the whole observation period. Probable causes of accidents were analyzed; technological accidents triggered by natural events (natural-technological accidents or NTA) were found out and investigated. The proportion of NTAs in the total number of technological accidents as well as a part of every NTA type in the total number of NTAs was estimated. A contribution of different natural hazards was also evaluated.

Two series of digital maps were created for the Russian federal regions using results of the statistical analyses. The first set of maps represents a mapping of triggers. Cartograms belonging to this set show regional distribution of NTAs triggered by different groups of natural hazards (for example, NTAs triggered by rainfall, snowfall, strong winds, etc.). One example is shown in Fig. 2 and the resulting map of all triggers - in Fig. 6. The second set of cartograms (Figs. 4 and 5) demonstrates regional differences in the average annual number of various types of technological accidents mentioned above (a mapping of accident types); the

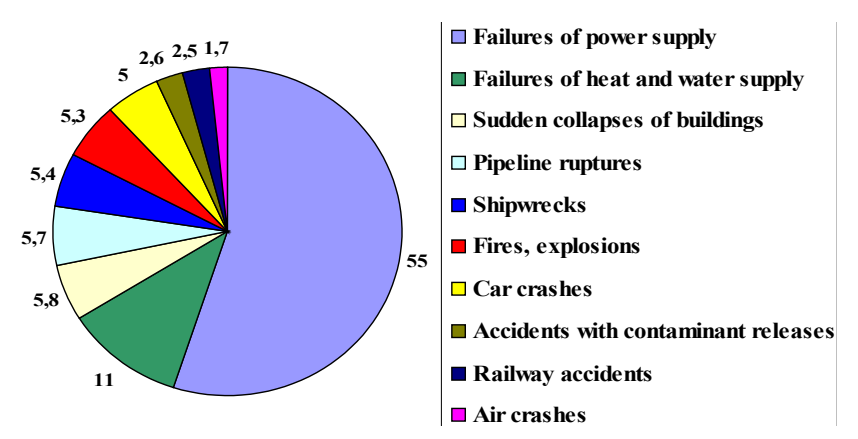

Fig. 3. Proportion of technological accidents triggered by natural hazards (in percent).

location of events caused by different natural hazards is also shown on these maps (Fig. 5).

\section{Results}

About 60 percent of all emergencies are produced in the Russian Federation by technological accidents and disasters, which account for more than 90 percent of all fatalities and more than 80 percent of all injured people. A total of 199 technological emergencies and 95 natural ones were recorded in the RF in 2010 (Statistics of emergencies, 2011). The most frequent technological accidents are fires (on average, more than 500 fires are registered per day) and traffic accidents. In 2010, fires caused 13067 injuries and 12983 deaths (Statistics of fires, 2011).

The main causes of technological accidents and disasters in Russia are technical, social, and economic ones (Petrova, 2008), including inexpedient arrangement of potentially hazardous objects within the country from the time of the former 
Table 1. Types of technological accidents triggered by natural hazards.

\begin{tabular}{|c|c|c|c|c|c|c|c|c|c|c|c|c|}
\hline $\begin{array}{l}\text { Natural } \\
\text { hazards }\end{array}$ & $\begin{array}{l}\text { Hurricanes, } \\
\text { cyclones, } \\
\text { windstorms, } \\
\text { squalls }\end{array}$ & $\begin{array}{l}\text { Snowfall, } \\
\text { snowstorms, } \\
\text { snowdrifts, } \\
\text { sleets }\end{array}$ & $\begin{array}{l}\text { Rainfall, } \\
\text { heavy } \\
\text { shower, } \\
\text { hailstones }\end{array}$ & $\begin{array}{l}\text { Hard frost, } \\
\text { icing, } \\
\text { ice-crusted } \\
\text { ground }\end{array}$ & $\begin{array}{l}\text { Thunder- } \\
\text { storm, } \\
\text { lightning }\end{array}$ & $\begin{array}{c}\text { Fogs, } \\
\text { mist }\end{array}$ & Floods & $\begin{array}{c}\text { Heat, } \\
\text { drought }\end{array}$ & $\begin{array}{l}\text { Earth- } \\
\text { quakes }\end{array}$ & $\begin{array}{l}\text { Land- } \\
\text { slides }\end{array}$ & $\begin{array}{l}\text { Subsidence of } \\
\text { ground, } \\
\text { slump, } \\
\text { debris flows }\end{array}$ & $\begin{array}{c}\text { Snow } \\
\text { avalanches }\end{array}$ \\
\hline \multicolumn{13}{|l|}{ Technological accidents } \\
\hline Failures of power supply & + & + & + & + & + & & + & + & + & + & & + \\
\hline Failures of heat supply & + & + & & + & & & & & + & + & & \\
\hline Failures of water supply & + & & + & + & & & & & + & & + & \\
\hline Car crashes & + & + & + & + & & + & & & & & + & + \\
\hline Railway accidents & & + & + & & & & + & + & & + & + & + \\
\hline Aircraft crashes & + & + & + & + & + & + & & & & & & \\
\hline Shipwrecks & + & + & & + & + & + & & & & & & \\
\hline Fires, explosions & & & & & + & & & + & & & & \\
\hline Pipeline ruptures & + & + & & + & & & + & & + & + & + & \\
\hline $\begin{array}{l}\text { Sudden collapses of } \\
\text { buildings and } \\
\text { constructions }\end{array}$ & + & + & + & + & & & + & & + & & + & \\
\hline $\begin{array}{l}\text { Accidents with } \\
\text { contaminant releases }\end{array}$ & & & + & & + & & + & & + & + & & \\
\hline
\end{tabular}

Soviet Union; poor quality of design, building, reconstruction and use; increasing consumption of capital assets and deterioration of infrastructure, transport, and industrial facilities; as well as the "human factor" (operational error, accidentally or intentionally caused damage to some facilities, etc.). For example, more than 40 percent of the fires are the result of human fault (careless handling of fire) (Statistics of fires, 2009). Many objects of the critical infrastructure in the RF were built in 1960-1980 and are nowadays beyond their service life (Petrova, 2011). Thus, the coefficient of wear of capital assets exceeds 50 percent in enterprises producing and distributing electric power, gas, heat, and drinking water; and 55 percent in transport and communication facilities (Russian statistical yearbook, 2009). In some Russian federal regions, both indicators are even higher than 60 percent (Regions of Russia, 2009).

The manifestation of the technical, social, and economic factors mentioned above not only leads to accidents, ruptures, and crashes directly, but also increases a vulnerability of the technosphere to natural impacts resulting in the severity and likelihood increasing of accidents (Petrova, 2006, 2009). The technosphere in the RF is exposed to the influence of more than 30 different types of disaster-causing natural hazards (Kurbatova et al., 1997; Petrova and Shnyparkov, 2004). The most destructive of these are hurricanes and storm winds, rainfall and snowfall, floods, earthquakes, landslides, geocryological processes, karsts, debris flows, snow avalanches, temperature extremes, and ground subsidence. These hazardous natural processes and phenomena not only produce a variety of natural disasters by themselves. Causing mechanical impacts on the infrastructure, industrial and other facilities, they thus become triggers for various naturaltechnological accidents (Petrova, 2005). In some cases, natural factors play a leading role in magnifying or triggering technological accidents.
The analysis of the data base revealed a proportion of accidents induced by natural events in the total number of technological accidents and disasters registered. It comes to about 10 percent; among some types of technological accidents this proportion is even higher. Thus, in 1991-2010, natural hazards and disasters triggered more than 70 percent of all so-called "blackouts" (accidental losses of electric power or power outages) in the RF, about 30 percent of breakdowns in water- and 18 percent in heat supply systems, about 30 percent of collapses of buildings or other constructions, and 17 percent of water transport accidents. They also caused about nine percent of pipeline ruptures, about five percent of accidents with oil release, about four percent of railway accidents, and about three percent of aircraft and car crashes, as well as other accidents with contaminant releases. The contribution of different natural hazards to the occurrence of various types of NTAs was also evaluated using information collected (Table 1). Most of them were triggered by hazardous hydrometeorological and related events. Criteria of hazardous weather events in Russia are listed in Table 2. In 1991-2010, 38 percent of all NTAs were induced by windstorms and hurricanes, 20 percent - by snowfalls, snowdrifts, and snowstorms, another 20 percent by rainfall and floods, 10 percent by hard frost and icing, 7 percent by landslides, karsts, rockfall, subsidence of ground and other slope processes, and more than 4 percent by thunderstorms and lightning.

Digital maps presenting regional distribution of NTAs caused by various groups of natural hazards in 1991-2010 were created at the level of the Russian federal regions. One example of this trigger mapping represents a cartogram in Fig. 2. It demonstrates differences between federal regions in the average annual number of accidents triggered by strong winds and hurricanes. They happen more often in the Far East of Russia as well as in some federal regions of the northwestern, southern, and central parts of the European Russia that are exposed to these hazards most of all. 


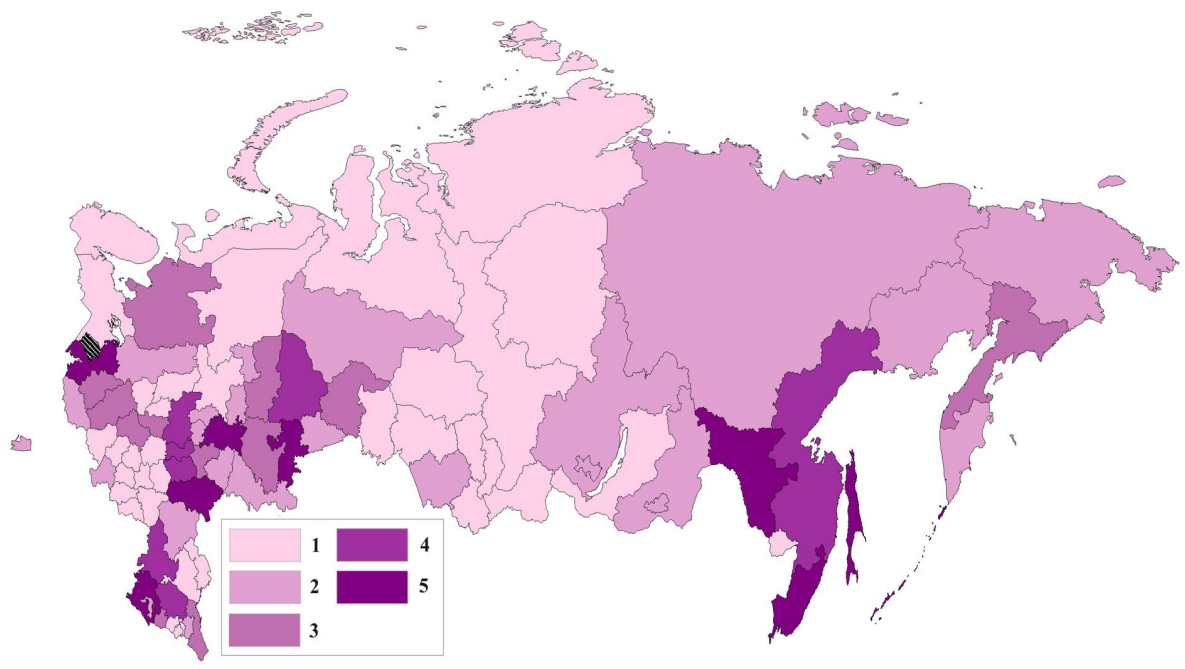

Fig. 4. Frequency of "blackouts" triggered by natural hazards (average annual number of events): $1-$ less than $0.1 ; 2-0.1-0.3 ; 3-0.4-0.6$; $4-0.7-0.9 ; 5-1$ and more.

Table 2. Criteria for hazardous weather events in Russia (according to the Hydrometeorological Centre of Russia).

\begin{tabular}{lll}
\hline \multirow{2}{*}{ Events } & \multicolumn{2}{c}{ Criteria } \\
\cline { 2 - 3 } & by intensity & by duration \\
\hline Strong winds including squall (max.speed, in gusts) & & \\
$\quad$ - on the sea coasts and in mountainous areas; & $\geq 35 \mathrm{~m} \mathrm{sec}^{-1}$ & any \\
$\quad$ - in other areas & $\geq 25 \mathrm{~m} \mathrm{sec}^{-1}$ & any \\
& & \\
Very heavy rain (rain and snow, sleet) & $\geq 50 \mathrm{~mm}$ & $\leq 12 \mathrm{~h}$ \\
Downpour (very heavy shower) & $\geq 30 \mathrm{~mm}$ & $\leq 1 \mathrm{~h}$ \\
Prolonged heavy rain & $\geq 100 \mathrm{~mm}$ & $\geq 12 \mathrm{~h} \leq 48 \mathrm{~h}$ \\
Very heavy snow & $\geq 20 \mathrm{~mm}$ & $\leq 12 \mathrm{~h}$ \\
Large hail & $\geq 20 \mathrm{~mm}$ & any \\
Severe snowstorm (including blowing snow) & & \\
predominant average wind speed & & $\geq 12 \mathrm{~h}$ \\
visibility & $\geq 15 \mathrm{~m} \mathrm{sec}$ & \\
Strong deposition (diameter) of & $\leq 500 \mathrm{~m}$ & \\
$\quad$ - ice & & \\
$\quad$ - rime & $\geq 20 \mathrm{~mm}$ & any \\
- wet snow sticking & $\geq 50 \mathrm{~mm}$ & any \\
Thick fog - visibility & $\geq 35 \mathrm{~mm}$ & any \\
\hline
\end{tabular}

A part of every NTA type in the total number of NTAs was estimated then (Fig. 3). The most frequent NTAs are breakdowns in electric power supply systems leading to "blackouts"; their proportion of all NTAs listed in the data base exceeds 55 percent. The "blackouts" are mainly caused by broken wires (including abruption of wires by falling trees) and transmission tower collapses due to strong winds, cyclones, and hurricanes; snowstorms; deposition of ice, sleet, and snow; rainfall, floods, and hailstones. Among other triggers of these accidents, earthquakes, hard frost, fierce heat, thunderstorms, landslides, snow avalanches, and debris flows should be mentioned. A great part of transmission facilities in Russia uses overhead lines (more than 90 percent); this situation makes them especially vulnerable to natural impacts, 


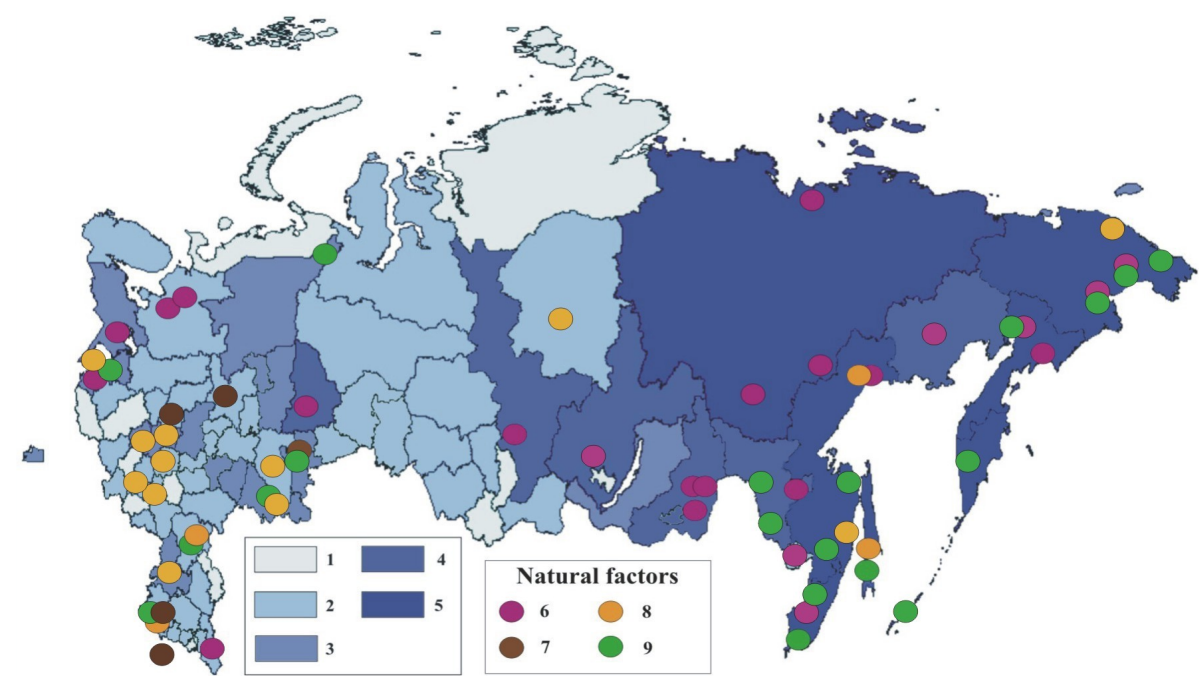

Fig. 5. Frequency of breakdowns in heat supply systems (average annual number of events): $1-$ less than $0.1 ; 2-0.1-0.3 ; 3-0.4-0.6 ; 4-$ $0.7-0.9 ; 5$ - 1 and more; 6 - hard frost, 7 - landslide; 8 - snow; 9 - strong wind.

taking into account the large length of power lines (more than 2.6 million km) (Russian statistical yearbook, 2009). Breakdowns in electric power supply systems due to natural factors occur more often in the Far East, in the Krasnodarskii Territory (south of Russia), in the northwestern part of European Russia, and in some regions of Central Russia (Fig. 4), which are particularly prone to hurricanes, cyclones, snowstorms, and heavy rainfall accompanied by hailstones, icing, and sleet. Thus, adverse weather phenomena (such as heavy snowfall that caused deposition of ice and snow on the wires) led to wire breakages and "blackouts" in six federal regions of the Central Russia in late December 2010. A total of about 445000 people were affected by power outages (Summary of emergencies, 2010). In some cases power outages, in their turn, can cause a chain of other accidents such as failures of heat- and water supply, industrial plants, and transport facilities producing the so-called "domino effect".

About 10 percent of all NTA registered in the data base comprise accidents at heat supply systems (in some cases, combined with failures of power supply) caused by hard frost (Far East, Siberia, North-West, and Ural), strong winds (Far East and Krasnodarskii Territories), snowfalls and snowstorms (Far East, north-western, central, and southern parts of the European Russia), and landslides (central, and southern parts of the European Russia). The location of events recorded is shown on the Fig. 5. In general, failures of heat supply systems occur most often in Sakha (Yakutia) Republic and in some federal regions of the Russian Far East.

Accidents with oil and other contaminant releases triggered by natural hazards, which are usually considered as Natechs, come to about 8 percent of all NTAs registered. They have especially severe consequences for the environment. For the most part, oil releases in the RF are caused by pipeline ruptures that were induced in 1991-2010 by landslides, subsidence of ground, frost heaving and other geocryological processes, earthquakes, heavy rainfall and floods, windstorms, and snow loads. In May 1995, the Neftegorsk earthquake caused about 200 oil pipeline ruptures with tens of thousands of tons of oil spill in the north part of Sakhalin Island. It was the greatest disaster registered in the data base. The oil storages are more vulnerable to the impact of floods, landslides, earthquakes, and lightning. In May 2001 a catastrophic flood destroyed a petroleum storage depot in Lensk, in the Republic of Sakha (Yakutia). More than 12 thousand tons of petroleum products flowed into the waters of the River Lena (Vorobyev et al., 2005).

As regards other NTA types (Fig. 3, Table 1), the following groups of natural hazards act as prevailing triggers of them:

- windstorms, snowfall, rainfall, hard frost, subsidence of ground, and other slope processes, or floods as triggers of sudden collapse of buildings or other constructions;

- hard frost, rainfall, landslides, or subsidence of ground as triggers of breakdowns in water supply systems;

- snowfall and snowstorms, icy conditions of roads, rainfall, fogs, mist, or snow avalanches as triggers of car crashes;

- storms, cyclones, typhoons, or fogs as triggers of water transport accidents (shipwrecks);

- snowdrifts and snowstorms, heavy rainfall and floods, landslides, snow avalanches, fierce heat, or rockfalls as triggers of railway accidents;

- windstorms, snowfall, icing, or fogs as triggers of aircraft crashes; 


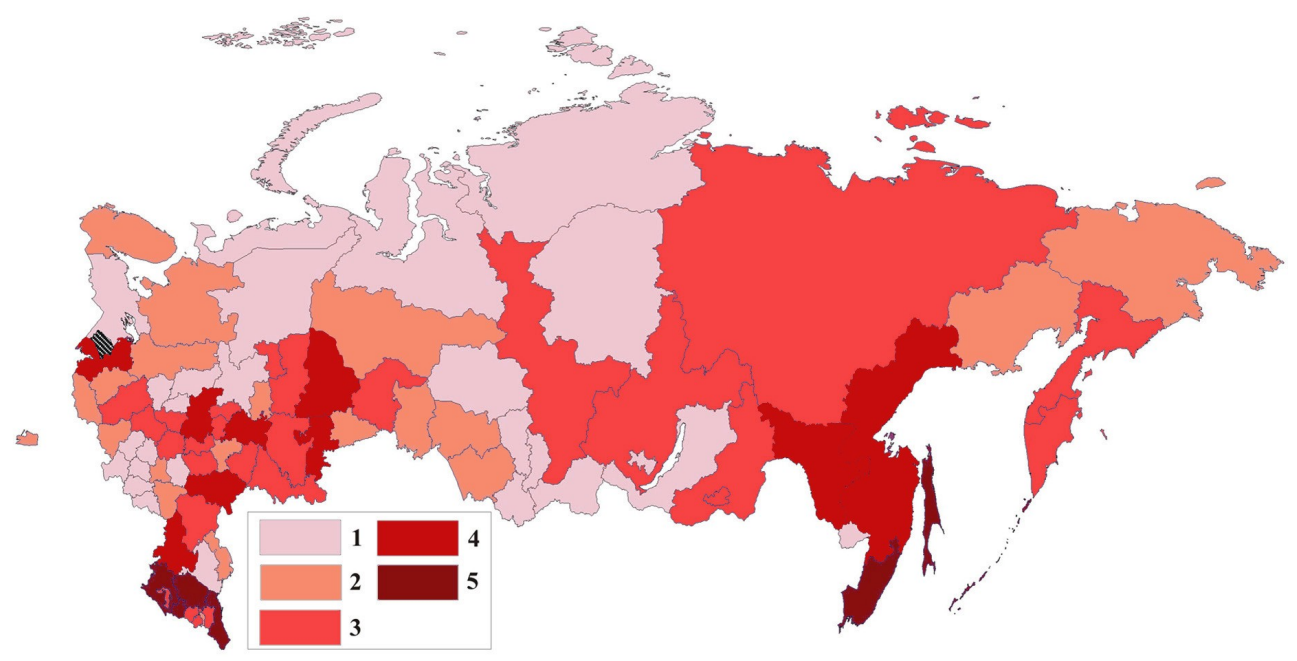

Fig. 6. Risk of NTA (calculated by the total number of events in 1991-2010): 1 - low (less than 6); 2 - average (6-10); 3 - above average (11-15); 4 - high (16-20); 5 - very high (more than 20).

- lightning or heat as triggers of fires and explosions;

- endogenous gas flows and methane accumulation as triggers of explosions and fires in coal-mines.

Figure 6 shows the resulting map of NTA risk in the Russian Federation. The risk level was calculated by the total number of events triggered by all types of natural hazards and disasters in 1991-2010. The greatest risk of their occurrence is seen in the Sakhalin Region (about 80 events registered during the whole observation period) as well as in the Primorskii (Far East) and Krasnodarskii Territories (south of the European Russia) (more than 50 events).

\section{Discussion and perspectives}

The data base of technological accidents and disasters has been created. More than 13000 information units have been collected and analyzed. The data base is replenished; new information is constantly being added to it.

The analysis of the information collected permitted examination of geographical distribution of technological accidents and disasters within Russian federal regions in 1991-2010. The main triggers of accidents were revealed. In addition to technical, economic, and social causes, natural hazards and disasters also played an essential (sometimes a leading) role in triggering or magnifying technological accidents. About 10 percent of all accidents registered in the data base were induced by natural events; among some types of accidents this proportion is even higher. Transmission facilities with more than 90 percent of overhead lines are the most vulnerable to the natural hazards impact. In 1991-2010, natural hazards and disasters triggered more than 70 percent of all "blackouts". The part of this NTA type in the total number of NTA was the largest one (more than 55 percent), too. Proportions of other NTA types were also estimated.

A contribution of different natural hazards to the occurrence of various types of NTAs was assessed. Regions with the greatest NTA risk were revealed for the RF. The influence of natural events on the technosphere is stronger in the southern part of the European Russia and in the Russian Far East, which are more exposed to strong winds, hurricanes, snowfall and snowstorms, rainfall, icing, and other natural hazards producing NTAs.

Most of the NTAs in the RF in 1991-2010 were caused by natural processes related to various hydrometeorological events and phenomena. It is to be expected that their intensity and frequency may increase towards the end of the century due to climate change. This may, in turn, increase the severity and likelihood of NTAs. For example, the increase in precipitation (especially in liquid form) in the cold season and alternation of thaw periods and cold spells may cause breakdowns of transmission facilities and other lines of communication as well as increasing the number of collapses of roofs and buildings and transport accidents. Potential permafrost thawing will produce a risk of building collapses, transmission and other facility failures, as well as roads, railways, and pipelines disruption in permafrost areas that comes to 63 percent in the total area of Russia.

Critical infrastructure facilities, especially those located in regions with the greatest NTA risk need a special protection and modernization. In particular, overhead power lines should be, where possible, replaced by underground cables. The pipelines, oil and other contaminant storages should be designed and equipped not only for normal operating conditions and "ordinary" technological accidents, but also to natural impacts that will be increasing. A monitoring of natural hazards producing NTAs, as well as gathering and analysing 
of accidents information is very important for risk management. Emergency planning and response should be prepared for coping with multiple and simultaneous accidents, which are typical for NTAs. The problem of relationship between natural hazards and technosphere is very complicated and needs further investigation, especially taking into consideration the climate changes expected.

Acknowledgements. Author would like to express her thanks to Elisabeth Krausmann, Bastien Affeltranger as well as to both other Referees for their very important notes that were very helpful for me by preparing my manuscript.

Edited by: E. Krausmann

Reviewed by: B. Affeltranger and two other anonymous referees

\section{References}

Krausmann, E. and Cruz, A. M.: Natech disasters: when natural hazards trigger technological accidents, Special Issue Nat. Hazard, 46(2), 139-263, 2008.

Kurbatova, A. S., Myagkov, S. M., and Shnyparkov, A. L.: Natural risk for the cities of Russia, Research Institute of the Urban Ecology, Moscow, 240 pp., 1997 (in Russian).

Model list and the criteria for hazardous weather events, in: Instruction on short-term weather forecasts, Hydrometeorological Centre of Russia, available at: http://meteoinfo.ru/ hazards-definitions (last access: 5 January 2011), 2002 (in Russian).

Petrova, E.: Natural hazards and technological risk in Russia: the relation assessment, Nat. Hazards Earth Syst. Sci., 5, 459-464, doi:10.5194/nhess-5-459-2005, 2005.

Petrova, E.: Vulnerability of Russian regions to natural risk: experience of quantitative assessment, Nat. Hazards Earth Syst. Sci., 6, 49-54, doi:10.5194/nhess-6-49-2006, 2006.

Petrova, E.: Natural hazards as pre-conditions of technological disasters in Russia, Georisk: assessment and management of risk for engineered systems and geohazards, Special Volume: Early warning systems and multidisciplinary approaches in natural hazard and risk assessment, 2(4), 248-256, 2008.
Petrova, E.: Natech Events in the Russian Federation, in: New perspectives on risk analysis and crisis response, Atlantis Press, Amsterdam-Paris, 46-52, 2009.

Petrova, E.: Critical infrastructure in Russia, Geographical analysis of accidents triggered by natural hazards, Environ. Eng. Manage. J., 10(1), 53-58, 2011.

Petrova, E. G. and Shnyparkov, A. L.: Sources of natural and technogenic risks, in: Geography, Society and Environment, Vol. IV, Natural-antropogenic processes and environmental risk, Gorodets Publishing House, Moscow, 274-279, 2004 (in Russian).

Regions of Russia, Social and economic indices, 2009: Statistical annual, Rosstat, Moscow, 990 pp., 2009 (in Russian).

Russian statistical yearbook, 2009: Statistical annual, Rosstat, Moscow, 795 pp., 2009.

Showalter, P. S. and Myers, M. F.: Natural disasters in the United States as release agents of oil, chemicals, or radiological materials between 1980-9: Analysis and recommendations, Risk Anal., 14(2), 169-181, 1994.

Statistics of emergencies in the Russian Federation in 2010: available at: http://www.mchs.gov.ru/stats/detail.php?ID=213821 (last access: 17 April 2011), 2011 (in Russian).

Statistics of fires in the Russian Federation in 2010: available at: http://www.mchs.gov.ru/stats/detail.php?ID=213801 (last access: 17 April 2011), 2011 (in Russian).

Steinberg, L. J. and Cruz, A. M.: When natural and technological disasters collide: Lessons from the Turkey earthquake of August 17, 1999, Nat. Hazards Review, 5(3), 121-130, 2004.

Summary of emergencies on 30 December 2010: available at: http: //www.mchs.gov.ru/digest/detail.php?ID=177971 (last access: 5 January 2011), 2010 (in Russian).

Vorobyev, Y. L., Akimov, V. A., and Sokolov, Y. I.: Prevention and Elimination of Oil and Oil Products Releases in Emergency Situations, Inoktavo Press, Moscow, 2005 (in Russian).

Young, S., Balluz, L., and Malilay, J.: Natural and Technologic hazardous material releases during and after natural disasters: A review, Sci. Total Environ., 322, 3-20, 2004. 